\title{
ANALISIS FAKTOR-FAKTOR YANG MEMPENGARUHI KEPATUHAN WAJIB PAJAK KENDARAAN BERMOTOR DENGAN SOSIALISASI PERPAJAKAN SEBAGAI VARIABEL MODERATING DI KOTA TANJUNGPINANG
}

\author{
Vanisa Meifari \\ Universitas Batam \\ vanisameifari@yahoo.co.id
}

\begin{abstract}
Abstrak: Hasil dari penelitian ini menunjukkan bahwa pengetahuan perpajakan berpengaruh signifikan terhadap kepatuhan wajib pajak, yang ditunjukkan dengan nilai signifikansi $0.008<0.05$, layanan pajak berpengaruh signifikan terhadap kepatuhan wajib pajak yang ditunjukkan dengan nilai signifikansi $0.007<0.05$, kesadaran wajib pajak berpengaruh signifikan terhadap kepatuhan wajib pajak yang ditunjukkan dengan nilai signifikansi $0.001<0.05$, sosialisasi perpajakan memperlemah pengaruh pengetahuan wajib pajak terhadap kepatuhan wajib pajak yang ditunjukkan dengan nilai signifikansi $0.007<0.05$ dengan nilai beta dari moderasi bernilai negatif, sosialisasi perpajakan tidak memoderasi pengaruh layanan fiskus terhadap kepatuhan wajib pajak yang ditunjukkan dengan nilai signifikansi $0.670>0.05$ dan sosialisasi perpajakan tidak memoderasi pengaruh kesadaran wajib pajak terhadap kepatuhan wajib pajak yang ditunjukkan dengan nilai signifikansi $0.164>0.05$.
\end{abstract}

Kata Kunci: Kepatuhan Wajib Pajak, Pengetahuan Perpajakan, Layanan Fiskus, Kesadaran Wajib Pajak dan Sosialisasi Perpajakan

\begin{abstract}
Abstrak : This research was conducted to examine and analyze the factors that influence taxpayer compliance with tax socialization as a moderating variable. Samples in this study were 100 motor vehicle taxpayers in SAMSAT Tanjungpinang City. The data used is primary data taken based on questionnaires distributed by incidental sampling technique. Data analysis techniques using multiple linear regression analysis and Moderated Regression Analysis (MRA).

The results of this study indicate that tax knowledge has a significant effect on taxpayer compliance, which is indicated by a significance value of $0.008<0.05$, tax services have a significant effect on taxpayer compliance as indicated by a significance value of $0.007<0.05$, taxpayer awareness has a significant effect on taxpayer compliance which is indicated by a significance value of $0.001<0.05$, tax socialization weakens the influence of taxpayer knowledge on taxpayer compliance as indicated by a significance value of $0.007<0.05$ with beta values of moderation negative, tax socialization does not moderate the effect of tax authorities' services on taxpayer compliance as indicated by significance value $0.670>0.05$ and tax socialization does not moderate the influence of taxpayer awareness on taxpayer compliance as indicated by a significance value of 0.164> 0.05 .
\end{abstract}

Keywords : Taxpayer Compliance, Taxation Knowledge, Tax Service, Taxpayer Awareness, Tax Socialization 


\section{PENDAHULUAN}

Pajak merupakan salah satu sumber pendapatan Negara yang sangat penting bagi pelaksanaan dan peningkatan pembangunan nasional, yang bertujuan untuk meningkatkan kesejahteraan bersama. Selama ini pajak berkontribusi 70 hingga 80 persen dalam APBN. Pada tahun 1970-an hingga awal 1980-an pendapatan Negara masih bertumpu pada sector minyak dan gas bumi (migas). Namun seiring dengan pertumbuhan jumlah penduduk, olahan hasil bumi yang bersifat tidak dapat diperbahrui ini mulai mnyusut, pemerintah beralih pada sector yang dinilai relative aman dan mendukung kesinambungan anggaran yaitu pajak. Kontribusi pajak dalam Anggaran Pendapatan dan Belanja Negara (APBN) setiap tahun semakin meningkat. Hal ini menunjukkan bahwa peranan pajak semakin besar dalam APBN. Oleh karena itu Direktorat Jenderal Pajak terus berupaya untuk meningkatkan penerimaan pajak.

Berdasarkan pemungut dan pengelola, pajak dikategorikan menjadi 2 (dua) jenis yaitu pajak pusat dan pajak daerah. Pajak pusat dipungut serta dikelola oleh Pemerintah Pusat sedangkan Pajak daerah dipungut serta dikelola oleh Pemerintah Daerah. Pajak kendaraan bermotor merupakan salah satu pajak daerah yang membiayai pembangunan daerah provinsi. Instansi yang menangani pembayaran pajak kendaraan bermotor adalah Dinas Pendapatan Daerah (Dispenda) melalui Kantor Bersama Sistem Administrasi Manunggal dibawah Satu Atap (SAMSAT) yang merupakan kerja sama tiga instansi terkait, yaitu Dispenda Provinsi Kepulauan Riau, Kepolisian Republik Indonesia dan Asuransi Jasa Raharja. Pajak ini adalah salah satu faktor pemasukan bagi negara yang cukup berkontribusi terhadap pendapatan negara dibandingkan dengan sektor pajak lainnya. Salah satu cara untuk mengoptimalkan penerimaan Pajak Kendaraan Bermotor adalah dengan meningkatkan kepatuhan Wajib Pajak Kendaraan Bermotor.

Salah satu upaya untuk meningkatkan kepatuhan Wajib Pajak adalah pengetahuan Wajib Pajak. Pengetahuan atas ketentuan maupun peraturan perpajakan yang berlaku sangat diperlukan, jika Wajib Pajak mengetahui ketentuan maupun peraturan perpajakan maka Wajib pajak akan lebih sadar dalam memenuhi kewajibannya dalam membayar pajak. Menurut Mardiasmo, (2016 : 7), pengetahuan perpajakan adalah segala sesuatu yang diketahui dan dipahami sehubungan dengan hukum, baik hukum pajak materiil maupun hukum pajak formil. Dengan adanya pengetahuan tentang pajak yang baik akan dapat memperkecil adanya tax evation. Pada penelitian yang dilakukan Paramartha dan Rasmini (2016) menyatakan bahwa pengetahuan memiliki pengaruh terhadap kepatuhan Wajib Pajak.

Faktor lainnya yaitu akuntabilitas pelayanan fiskus dari daerah setempat. Kualitas pelayanan menurut teori atribusi merupakan penyebab eksternal yang mempengaruhi persepsi Wajib Pajak untuk membuat penilaian mengenai perilaku kepatuhan Wajib Pajak dalam melaksanakan kewajiban perpajakan. Pelayanan 
yang berkualitas membuat wajib pajak patuh dalam membayar pajak. Perasaan senang dan puas atas pelayanan yang diberikan oleh pemerintah dapat memicu motivasi dan kepatuhan bagi Wajib Pajak yang akhirnya dapat meningkatkan penerimaan negara. Berdasarkan penelitian yang dilakukan oleh Paramartha dan Rasmini (2016) kualitas pelayanan berpengaruh positif terhadap kepatuhan wajib pajak badan.

Selain faktor- faktor diatas, kepatuhan Wajib Pajak dalam memenuhi kewajiban perpajakannya juga dipengaruhi oleh kesadaran Wajib Pajak. Kesadaran Wajib Pajak adalah suatu kondisi dimana Wajib pajak mengetahui, mengakui, menghargai dan meneliti ketentuan perpajakan yang berlaku serta memiliki kesanggupan dan kemauan untuk memenuhi kewajiban pajaknya. Kesadaran Wajib Pajak meningkat jika masyarakat mempunyai presepsi positif tentang pajak, meningkatnya pengetahuan perpajakan, baik formal maupun informal akan memberikan dampak positif terhadap kesadaran Wajib Pajak untuk membayar. Wajib Pajak yang memiliki kesadaran rendah akan cenderung untuk tidak melaksanakan kewajiban perpajakannya atau melanggar peraturan perpajakan yang berlaku. Ditambah lagi dengan fenomena yang ditemukan penulis, beberapa masyarakat yang sudah menunggak, akan mengandalkan kebijakan pemutihan denda dari pemerintah, jadi tidak ada kesadaran dari diri sendiri untuk patuh membayar pajaknya setiap tahun. Hal ini didukung oleh penelitian Megawangi dan Setiawan (2017) yang menyimpulkan bahwa kesadaran wajib pajak berpengaruh signifikan terhadap kepatuhan Wajib Pajak.

Solusi atas penghindaran ketidakpatuhan wajib pajak ini adalah dengan melakukan sosialisasi. Dengan adanya sosialisasi diharapkan akan meningkatkan kepatuhan masyarakat dalam membayar pajak. Hingga saat ini pemerintah telah melakukan beberapa terobosan baru dalam mensosialisasikan peran pemungutan pajak kepada masyarakat, misalnya kemajuan dalam bentuk sosialisasi perpajakan, seperti diselenggarakannya acara sosialisasi perpajakan di berbagai media dengan format yang cukup interaktif. Dengan sosialisasi ini masyarakat menjadi mengerti dan paham tentang manfaat membayar pajak serta sanksi jika tidak membayar pajak. Secara otomatis pula tingkat kepatuhan wajib pajak akan semakin bertambah dan penerimaan pajak negara akan meningkat. Hal ini didukung penelitian Dharma dan Ketut (2014) yang menemukan bahwa sosialisasi perpajakan berpengaruh terhadap kepatuhan Wajib Pajak.

Kota Tanjungpinang adalah ibukota Provinsi Kepulauan Riau yang saat ini sedang terus berkembang. Hal ini mempengaruhi jumlah tingkat penduduk dan secara tidak langsung mempengaruhi jumlah kendaraan yang ada. Seiring adanya peningkatan jumlah kendaraan bermotor dan Wajib Pajak di Tanjungpinang dari waktu ke waktu maka perlu diperhatikan dan ditingkatkan kepatuhan Wajib Pajak dalam membayar pajaknya agar fungsi pajak dapat diwujudkan. 
Kepatuhan wajib pajak untuk membayar pajak tidak tumbuh di masyarakat disebabkan adanya perbedaan kepentingan antara wajib pajak dengan pemerintah dalam pelaksanaan perpajakan. Sampai sekarang masih banyak masyarakat yang beranggapan bahwa pajak merupakan pungutan bersifat paksaan yang merupakan hak istimewa pemerintah dengan tidak memberikan kontraprestasi langsung kepada pembayar pajak. Sehingga membayar pajak bukanlah merupakan tindakan yang semudah dan sesederhana membayar untuk mendapatkan sesuatu bagi masyarakat, tetapi di dalam pelaksanaannya penuh dengan hal yang bersifat emosional (Carolina, 2012).

Terjadinya ketidakpatuhan membayar pajak kendaraan bermotor tersebut mengindikasikan adanya faktor-faktor yang mempengaruhi kepatuhan wajib pajak. Ketika faktor tersebut tidak berjalan sebagaimana mestinya, maka wajib pajak memilih mengabaikan kepatuhannya. Hal ini menjadi penting untuk dikaji dalam rangka optimalisasi penerimaan pajak kendaraan bermotor di Propinsi Kepulauan Riau, khususnya di Kota Tanjungpinang. Meskipun sudah terdapat peraturan perundang-undangan dan peraturanperaturan yang dibuat oleh Pemerintah Daerah untuk mendasari kewajiban perpajakan pajak kendaraan bermotor dan berbagai strategi kepatuhan yang dilakukan instansi pemungut, masih terdapat wajib pajak kendaraan bermotor yang tidak patuh. Fenomena yang terjadi di lapangan, setiap instansi menggelar razia dalam satu waktu di tempat-tempat tertentu Kota Tanjungpinang, di dalam pelaksanaanya masih banyak terdapat setidaknya kurang lebih puluhan kendaraan yang masih menunggak pembayaran pajak kendaraannya bertahun-tahun. Hal tersebut sangat mengganggu peranan pajak kendaraan bermotor sebagai sumber penerimaan pemerintah daerah.

Penelitian ini akan mengkaji seberapa besar tingkat kepatuhan dalam melakukan kewajiban sebagai wajib pajak kendaraan bermotor. Faktor yang menjadi penyebab tinggi rendahnya tingkat kepatuhan wajib pajak antara lain pengetahuan perpajakan, layanan fiskus dan kesadaran dari wajib pajak itu sendiri, serta sosialisasi pajak terhadap wajib pajak dari instansi yang bersangkutan. Pentingnya kepatuhan wajib dalam membayar

pajak kendaraan bermotor guna mencapai pendapatan pajak yang optimal membuat peneliti tertarik dan perlu untuk melakukan penelitan dengan judul "Analisis Faktor-faktor yang Mempengaruhi Kepatuhan Wajib Pajak kendaraan Bermotor dengan Sosialisasi Perpajakan Sebagai Variabel Moderasi di Kota Tanjungpinang."

\section{Batasan Masalah}

Dengan begitu luasnya cakupan kepatuhan wajib pajak dalam penelitian ini, penulis hanya membatasi pada tiga variabel independen yang terdiri dari Pengetahuan Perpajakan, Layanan Fiskus dan Kesadaran Wajib Pajak ; variabel dependen yaitu Kepatuhan Wajib Pajak Kendaraan Bermotor dengan Sosialisasi Perpajakan sebagai variabel moderasi. Objek penelitian pada 
Kantor Bersama SAMSAT Tanjungpinang disebabkan karena adanya keterbatasan sarana, prasarana, waktu dan biaya. Disamping itu, pengetahuan perpajakan, layanan fiskus dan kesadaran wajib pajak merupakan faktor yang sangat penting bagi kepatuhan wajib pajak karena akan berpengaruh terhadap penerimaan pajak daerah di Tanjungpinang ini.

\section{Tujuan Penelitian}

Tujuan penelitian ini adalah : (1) Untuk menguji dan menganalisis pengaruh pengetahuan perpajakan terhadap kepatuhan wajib pajak di Kota Tanjungpinang; (2) Untuk menguji dan menganalisis pengaruh layanan fiskus terhadap kepatuhan wajib pajak di Kota Tanjungpinang; (3) Untuk menguji dan menganalisis pengaruh kesadaran wajib pajak terhadap kepatuhan wajib pajak di Kota Tanjungpinang; (4) Untuk menguji dan menganalisis apakah sosialisasi perpajakan memoderasi pengaruh pengetahuan perpajakan terhadap kepatuhan wajib pajak di Kota Tanjungpinang; (5) Untuk menguji dan menganalisis apakah sosialisasi perpajakan memoderasi pengaruh layanan fiskus terhadap kepatuhan wajib pajak di Kota Tanjungpinang; (6) Untuk menguji dan menganalisis apakah sosialisasi perpajakan memoderasi pengaruh kesadaran wajib pajak terhadap kepatuhan wajib pajak di Kota Tanjungpinang.

\section{TINJAUAN PUSTAKA}

\section{Teori Kepatuhan}

Teori kepatuhan (compliance theory) merupakan teori yang menjelaskan suatu kondisi dimana seseorang taat terhadap perintah atau aturan yang diberikan. Menurut Tahar dan Rachman (2014) kepatuhan mengenai perpajakan merupakan tanggung jawab kepada Tuhan, bagi pemerintah dan rakyat sebagai Wajib Pajak untuk memenuhi semua kegiatan kewajiban perpajakan dan melaksanakan hak perpajakannya. Menurut Rahayu (2010 : 138), menyatakan bahwa kepatuhan perpajakan dapat didefinisikan sebagai suatu keadaan dimana wajib pajak memenuhi semua kewajiban perpajakan dan melaksanakan hak perpajakannya. Menurut Gunadi (2013 : 94) kepatuhan wajib pajak dapat diartikan bahwa wajib pajak mempunyai kesediaan untuk memenuhi kewajiban perpajakannya sesuai dengan aturan yang berlaku tanpa perlu diadakannya pemeriksaan, investigasi seksama, peringatan ataupun ancaman dan penerapan sanksi baik hukum maupun administrasi. Variabel ini diukur menggunakan skala Likert 5 poin dengan indikator akurasi dan kepatuhan.

\section{Pengetahuan Perpajakan}

Menurut Mardiasmo, (2016 : 7), pengetahuan perpajakan adalah segala sesuatu yang diketahui dan dipahami sehubungan dengan hukum, baik hukum pajak materiil maupun hukum pajak formil. Pengetahuan perpajakan sangat penting untuk menumbuhkan perilaku patuh. Karena bagaimana mungkin wajib pajak patuh apabila mereka tidak mengetahui bagaimana peraturan perpajakannya. Dengan adanya pengetahuan tentang pajak yang baik akan memperkecil adanya tax evation (Witono, 2008). Variabel ini diukur menggunakan skala Likert 5 poin dengan 
indikator ketentuan umum dan prosedur perpajakan, sistem perpajakan, dan fungsi pajak.

\section{Layanan Fiskus}

Menurut Yulianawati (2011), kualitas layanan adalah pelayanan yang dapat memberikan kepuasan kepada pelanggan dan tetap dalam batas memenuhi standar pelayanan yang dapat dipertanggungjawabkan serta harus dilakukan secara terus-menerus. Kualitas pelayanan dapat diartikan sebagai upaya pemenuhan kebutuhan dan keinginan konsumen serta ketepatan penyampaiannya dalam mengimbangi harapan konsumen (Tjiptono, 2007). Variabel ini diukur menggunakan skala Likert 5 poin dengan indikator Tangible, Realibility, Responsiveness, Assurance dan Emphaty.

\section{Kesadaran Wajib Pajak}

Menurut Kamus Besar Bahasa Indonesia, kesadaran adalah keadaan tahu, mengerti dan merasa. Menurut Ritongga (2011) kesadaran adalah perilaku atau sikap terhadap suatu objek yang melibatkan anggapan dan perasaan serta kecenderungan untuk bertindak sesuai objek tersebut. Kesadaran untuk memenuhi ketentuan hukum pajak yang berlaku tentu menyangkut faktor-faktor apakah ketentuan tersebut telah diketahui, diakui, dihargai dan ditaati. Bila seseorang hanya mengetahui berarti kesadaran wajib pajak tersebut masih rendah. Variabel ini diukur menggunakan skala Likert 5 poin dengan indikator Manfaat Sukarela, Partisipatif dan Pajak.

\section{Sosialisasi Perpajakan}

Sosialisasi menurut Kamus Besar Bahasa Indonesia adalah upaya memasyarakatkan sesuatu hingga menjadi dikenal, dipahami, dihayati oleh masyarakat. Menurut Dharma (2014) sosialisasi perpajakan merupakan upaya memberikan pengertian, informasi, dan pembinaan kepada masyarakat pada umumnya dan wajib pada khususnya mengenai segala sesuatu yang berhubungan dengan perpajakan dan perundang-undangan. Variabel ini diukur dengan menggunakan Skala Likert 5 poin dengan indikator Sosialisasi Pengorganisasian, Sosialisasi Media, dan Manfaat Sosialisasi.

\section{METODE PENELITIAN}

Metode penelitian menggunakan metode survei dengan analisis regresi linier berganda dan Moderated Regression Analysis (MRA). Populasi dalam penelitian ini adalah semua wajib pajak bermotor yang tercatat di SAMSAT Tanjungpinang. Teknik pengambilan sampel yang digunakan adalah insidental sampling (accidental sampling). Accidental sampling adalah teknik pengambilan sampel berbasis kebetulan, bahwa siapa saja yang secara tidak sengaja / kebetulan bertemu dengan seorang peneliti dapat digunakan sebagai sampel, jika dilihat oleh seseorang yang kebetulan cocok sebagai sumber data (Sugiyono, 2012: 122). Jumlah kuesioner yang didistribusikan dalam penelitian ini adalah 100 kuesioner. Waktu dan batas pengambilan quizer ditentukan 1 (satu) bulan dari 1 Juni 2018 hingga 30 Juni 2018. Untuk melakukan uji kualitas data atas data 
primer ini, maka peneliti menggunakan uji validitas dan reliabilitas. Menurut Ghozali (2011:52) uji validitas digunakan untuk mengukur sah atau valid tidaknya suatu kuesioner. Suatu kuesioner dikatakan valid jika pertanyaan pada kuesioner mampu untuk mengungkapkan sesuatu yang akan diukur oleh kusioner tersebut.

\section{Model Penelitian}

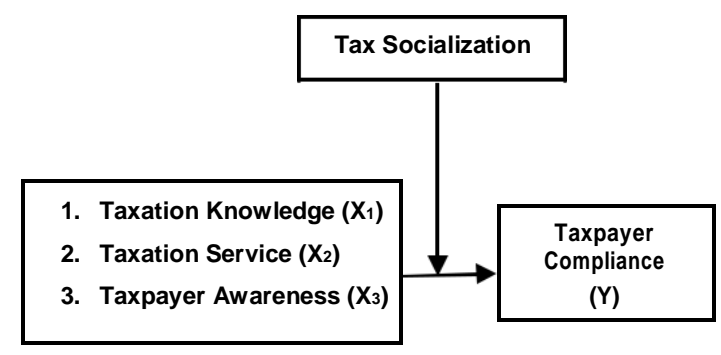

\section{HASIL DAN PEMBAHASAN}

\section{Uji Normalitas}

Uji normalitas dilakukan untuk melihat apakah nilai residual terdistribusi normal atau tidak. Model regresi yang baik adalah memiliki nilai residual yang terdistribusi normal dan dapat dilihat dengan pengujian Kolmogorov-Smirnov dan uji grafik. Dapat dilihat bahwa dari hasil pengolahan data mendapatkan gambar titik yang mengikuti data sepanjang garis diagonal.

\section{Gambar 4.1}

\section{Uji Normalitas}

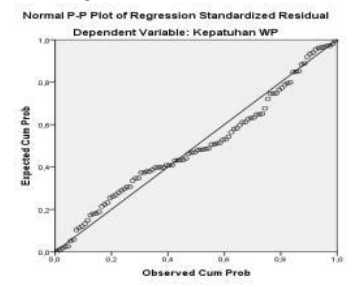

ketidaksamaan varians dari residual dari suatu pengamatan yang lain. Dasar pengambilan

\section{Uji Multikolinieritas}

Uji tentang multikolinearitas bertujuan untuk menguji apakah model regresi ditemukan adanya korelasi antara variabel bebas ( independen ).Model regresi yang baik seharusnya tidak terjadi korelasi diantara variabel independen. Nilai tolerance yang rendah sama dengan nilai Value Inflation Factor (VIF) tinggi (karena VIF = 1/Tolerance). Nilai untuk mengetahui Multikolinieritas adalah nilai Tolerance $<0,10$ atau sama dengan nilai VIF > 10, atau dengan dapat dilihat dari Value Inflation Factor (VIF). Apabila nilai VIF $>10$, terjadi multikolinieritas. Sebaliknya jika $\mathrm{VIF}<10$, tidak terjadi multikolinieritas ( Wijaya, 2009 :119).

Tabel 4.2

\section{Uji Multikolinearitas}

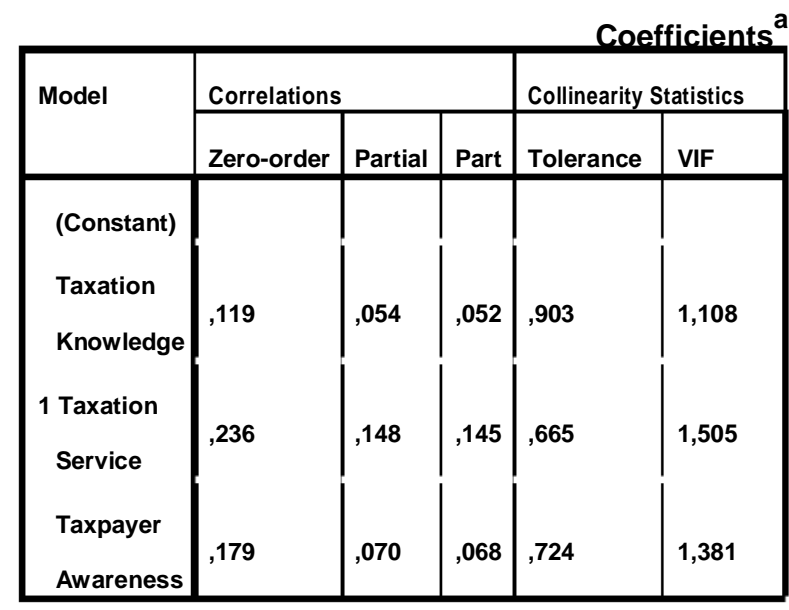

a. Dependent Variable: Taxpayer Comliance

\section{Uji Heterokedasitas}

Heterokedastisitas digunakan untuk menguji apakah dalam model regresi, terjadi keputusannya adalah jika pola tertentu seperti titik-titik (poin-poin) yang ada membentuk 
suatu pola tertentu yang teratur, maka terjadi heterokedastisitas. Jika tidak ada pola yang jelas serta titik-titik menyebar di bawah dan di atas angka 0 pada sumbu $\mathrm{Y}$, maka tidak terjadi heterokedastisitas.

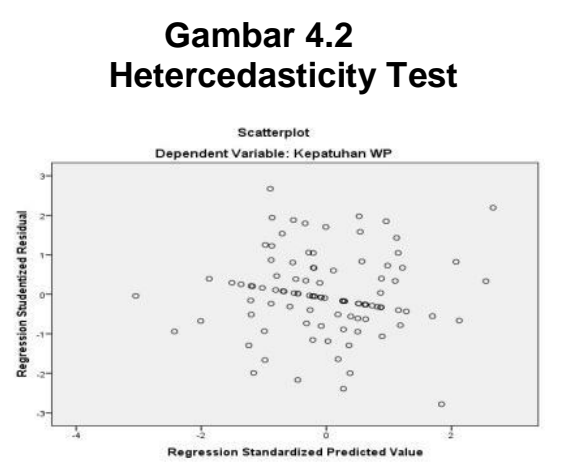

\section{Uji Hipotesis}

Uji Koefisien Determinasi R-Square

Model Summary
Model
\begin{tabular}{|l|r|rr|r|}
\hline & R & \multicolumn{1}{c}{ R } & Adjusted R Std. Error of the \\
& & Square & Square & Estimate \\
1 &, $751^{\mathrm{a}}$ &, 603 &, $43 \$$ & $\mathbf{2 , 8 0 1 9 1}$ \\
\hline Sourcd & $\mathrm{S}$ : Prilmary data are prodessed, 2018 \\
\hline
\end{tabular}

Data di atas menunjukkan nilai Adjusted RSquare sebesar 0.433 , hal ini berarti bahwa 43.3 \% variasi nilai Kepatuhan Wajib Pajak Kendaraan Bermotor (Y) dapat dijelaskan oleh variasi dari ketiga variable independen yaitu :Pengetahuan Perpajakan (X1), Layanan Fiskus (X2) dan Kesadaran Wajib Pajak (X3). Sedangkan sisanya $56,7 \%$ dijelaskan oleh sebab-sebab lain yang tidak diteliti dalam penelitian ini dan Standard Error Of Estimate ( SEE ) 2,80191.

\section{Analisis Regresi Linier Berganda}

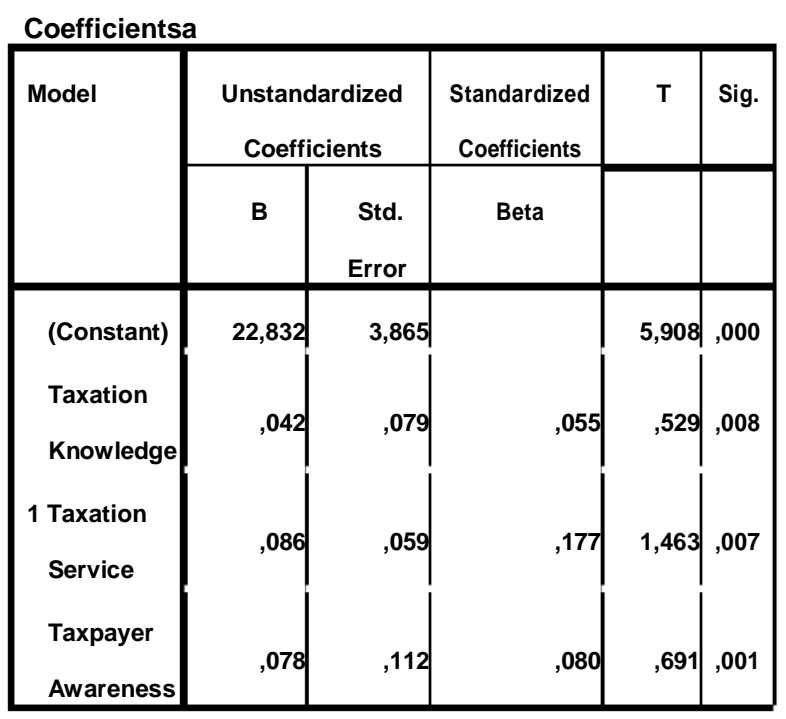

a. Dependent Variable: Kepatuhan WP

\section{Pengujian Hipotesis I : Pengetahuan}

Perpajakan berpengaruh signifikan terhadap Kepatuhan Wajib Pajak Kendaraan Bermotor

Dari hasil pengolahan data di atas terlihat bahwa nilai probabilitas $\mathrm{t}$ (Sig) kompetensi adalah sebesar 0.008 (Sig.008< <0.05). Hasil ini berarti menolak H0 dan menerima Ha dengan hipotesis 1 yang menyatakan pengetahuan perpajakan berpengaruh signifikan terhadap kepatuhan wajib pajak. Secara parsial ada pengaruh signifikan pengetahuan perpajakan terhadap kepatuhan wajib pajak kendaraan bermotor.

\section{Pengujian Hipotesis II : Layanan Fiskus berpengaruh terhadap Kepatuhan Wajib Pajak Kendaraan Bermotor}

Dari hasil uji parsial (t) menunjukkan bahwa variabel layanan fiskus berpengaruh signifikan 
terhadap kepatuhan wajib pajak kendaraan bermotor. Hal ini dapat dilihat bahwa nilai probabilitas t (Sig) layanan fiskus adalah sebesar 0.007 (Sig.007 < a0.05). Hasil ini berarti menolak H0 dan menerima Ha dengan hipotesis 2 yang menyatakan layanan fiskus berpengaruh signifikan terhadap kepatuhan wajib pajak.

\section{Pengujian Hipotesis III : Kesadaran Wajib} Pajak berpengaruh terhadap Kepatuhan Wajib Kendaraan Bermotor

Dari hasil uji parsial (t) menunjukkan bahwa variabel kesadaran wajib pajak berpengaruh signifikan terhadap kepatuhan wajib pajak kendaraan bermotor. Hal ini dapat dilihat bahwa nilai probabilitas $\mathrm{t}$ (Sig) layanan fiskus adalah sebesar 0.001 (Sig.001< <0.05). Hasil ini berarti menolak H0 dan menerima Ha dengan hipotesis 3 yang menyatakan kesadaran wajib pajak berpengaruh signifikan terhadap kepatuhan wajib pajak.

Moderate Regression Analysis (MRA) Pengujian Hipotesis IV : Sosialisasi Perpajakan Memoderasi Pengetahuan Perpajakan Terhadap Kepatuhan Wajib Pajak Kendaraan Bermotor

Dari hasil pengolahan data di atas terlihat bahwa nilai probabilitas $\mathrm{t}$ (Sig) moderator adalah sebesar 0.007 (Sig.007< <0.05). Masuknya sosialisi perpajakan mampu secara signifikan memoderasi pengaruh pengetahuan perpajakan terhadap kepatuhan wajib pajak kendaraan bermotor. Hal ini dapat di lihat bahwa signifikansi sebesar 0.007 dan signifikansi lebih kecil dari Los ( Level of significance) 0.05 maka Ho ditolak (0.007 < 0.05). Hal ini menunjukkan bahwa sosialisasi memoderasi pengaruh pengetahuan perpajakan terhadap kepatuhan wajib pajak.

\section{Pengujian Hipotesis V : Sosialisasi Perpajakan Memoderasi Layanan Fiskus terhadap Kepatuhan Wajib Pajak Kendaraan Bermotor.}

Dapat di lihat bahwa signifikansi sebesar 0.670 dan signifikansi lebih besar dari Los ( Level of significance) 0.05 maka Ho di terima (0.670 > 0.05). Hal ini menunjukkan bahwa sosialisasi perpajakan belum memenuhi seluruh komponen penilaian dari pada layanan fiskus.

\section{Pengujian Hipotesis VI : Sosialisasi Perpajakan Memoderasi Wajib Pajak Terhadap Kepatuhan Wajib Pajak}

\section{Kendaraan Bermotor}

Dapat di lihat bahwa signifikansi sebesar 0.164 dan signifikansi lebih besar dari Los ( Level of significance) 0.05 maka Ho di terima (0.164 > 0.05). Hal ini menunjukkan bahwa sosialisasi perpajakan belum memenuhi seluruh komponen penilaian dari pada kesadaran wajib pajak.

\section{KESIMPULAN}

Kesimpulan dari penelitian ini adalah: (1) Pengetahuan perpajakan sebagai variabel independen berpengaruh signifikan terhadap kepatuhan wajib pajak; (2) Layanan fiskus sebagai variabel independen berpengaruh 
signifikan terhadap kepatuhan wajib pajak; (3) Kesadaran wajib pajak sebagai variabel independen berpengaruh signifikan terhadap kepatuhan wajib pajak; (4) Sosialisasi perpajakan memoderasi pengaruh pengetahuan perpajakan terhadap kepatuhan wajib pajak; (5) Sosialisasi perpajakan tidak memoderasi pengaruh layanan fiskus terhadap kepatuhan wajib pajak; (6) Sosialisasi perpajakan tidak memoderasi pengaruh kesadaran wajib pajak terhadap kepatuhan wajib pajak.

\section{KETERBATASAN PENELITIAN}

Keterbatasan dalam penelitian ini adalah : (1) Hasil penelitian ini hanya dapat dijadikan bahan analisis pada objek penelitian yang terbatas pada ruang lingkup unit pelayanan SAMSAT Tanjungpinang sehingga akan terdapat perbedaan hasil penelitian dan kesimpulan apabila penelitian dilakukan pada objek penelitian yang berbeda; (2) Penelitian yang menggunakan kuisioner sebagai teknik pengumpulan data memungkinkan data yang dihasilkan terjadi bias. Kemungkinan adanya bias tersebut disebabkan adanya perbedaan persepsi antara peneliti dan responden terhadap pernyataan-pernyataan yang diajukan;

Responden penelitian merespon pernyataanpernyataan yang terdapat pada kuisioner dengan memberikan penilaian terhadap diri sendiri yang kemungkinan jawaban responden tidak menunjukkan keadaan yang sesungguhnya sehingga memungkinkan data yang dihasilkan bias; (4) Masih banyak variabel lain yang dapat mempengaruhi tingkat kepatuhan wajib pajak tidak hanya variabel yang digunakan di dalam penelitian ini.

\section{SARAN}

Saran dalam penelitian ini adalah : (1) Bagi penelitian selanjutnya agar menambahkan variabel atau faktor-faktor lainnya yang mempengaruhi tingkat kepatuhan wajib pajak, seperti sanksi administrasi, transparansi dan lainnya; (2) Penelitian selanjutnya agar meneliti tidak hanya di SAMSAT Tanjungpinang, tetapi mencakup seluruh unit SAMSAT di Provinsi Kepulauan Riau (3) Pemerintah sebaiknya meningkatkan sosialisasi perpajakan kepada para wajib pajak kendaraan bermotor secara rutin dan kontinyu, sosialisasi yang dilakukan akan berdampak pada meningkatnya kepatuhan artinya, pemerintah harus lebih memperhatikan metode sosialisasi perpajakan yang lebih efektif agar tujuan dari sosialisasi yaitu kepatuhan wajib pajak dapat meningkat, karena sosialisasi diharapkan dapat berkontribusi secara banyak terhadap usaha peningkatan kepatuhan wajib pajak; (4) Kualitas layanan fiskus yang diberikan hendaknya selalu dijaga dan ditingkatkan, karena pelayanan yang optimal akan menjadi motivasi bagi wajib pajak untuk memenuhi kewajiban perpajakannya, sehingga kepatuhan wajib pajak akan meningkat; (5) Pemerintah dapat memperluas sosialisasi dengan melibatkan peran pendidik dalam meningkatkan kesadaran masyarakat dalam membayar pajak kendaraan bermotor dengan cara mengaitkan 
materi pembelajaran dengan pengetahuan kepada siswa sekolah sehingga diharapkan kesadaran patuh membayar pajak tumbuh sejak dini; (6) Pemerintah dapat meningkatkan citra good governance, agar para wajib pajak selalu patuh dan yakin akan gunanya membayar pajak.

\section{DAFTAR PUSTAKA}

Amalia, Rizki, Topowijono dan Dwiatmanto. 2016. Pengaruh Pengenaan Sanksi Administrasi Dan Kesadaran Wajib Pajak Terhadap Tingkat Kepatuhan Wajib Pajak Kendaraan Bermotor di Kabupaten Bengkalis Riau. Jurnal Administrasi Bisnis (JAB) Vol. 31 No. 1, pp: 35-41.Arikunto, S. 2013. Prosedur Penelitian: Suatu Pendekatan Praktik. Jakarta: Rineka Cipta.

Ginting, Angela Vita Loka, Harijanto Sabijono dan Winston Pontoh. 2017. Peran Motivasi dan Pengetahuan Perpajakan Terhadap Kepatuhan Wajib Pajak (Studi Empiris Pada WPOP Kecamatan Malalayang Kota Manado). Jurnal EMBA Vol.5 No.2.

Barus, Stephanie Amelia Handayani. 2016. Pengaruh Akses Pajak, Fasilitas, Sosialisasi Perpajakan dan Kualitas Pelayanan Terhadap Kepatuhan Wajib Pajak Kendaraan Bermotor di Kota Pekanbaru. EJurnal Akuntansi Universitas Riau.

Carolina, Veronica. 2009. Pengetahuan Pajak. Jakarta : Salemba Empat.

Caroline, Verani, dkk. 2012. Dasar Pelaksanaan Reformasi Perpajakan Menuju Kepatuhan
Sukarela. Jurnal. Madur : Universitas Trunojoyo.

Dharma, Gede Pani Esa., dan Ketut Alit Suardana. 2014. Pengaruh Kesadaran Wajib Pajak, Sosialisasi Perpajakan, Kualititas Pelayanan Pada Kepatuhan Wajib Pajak. E-Jurnal Akuntansi Universitas Udayana 6.1, pp: 340-353.

Fany, Aulia Rezy. 2013. Pengaruh Kesadaran Wajib Pajak Terhadap Kepatuhan Membayar Pajak Dengan Sosialisasi Sebagai Variabel Moderasi. Universitas Jember.

Ghozali, Imam. 2011. "Aplikasi Analisis Multivariate Dengan Program SPSS". Semarang: Badan Penerbit Universitas Diponegoro.

Ginting, Angela Vita Loka, Harijanto Sabijono dan Winston Pontoh. 2017. Peran Motivasi dan Pengetahuan Perpajakan Terhadap Kepatuhan Wajib Pajak (Studi Empiris Pada WPOP Kecamatan Malalayang Kota Manado). Jurnal EMBA Vol.5 No.2, pp: 1998-2006.

Gunadi. 2013. Panduan Komprehensif Pajak Penghasilan. Jakarta: Bee Media Indonesia Herryanto, Marisa dan Agus Arianto Toly. 2013. "Pengaruh Kesadaran Wajib Pajak, Kegiatan Sosialisasi Perpajakan, dan Pemeriksaan Pajak terhadap Penerimaan Pajak Penghasilan di KPP Pratama Surabaya Sawahan". Tax \& Accounting Review, Vol. 1,No.1, pp: 124-135. 
Hardiningsih, Pancawati dan Nila Yulianawati. 2011. Faktor-faktor yang Mempengaruhi Kemauan Membayar Pajak. Dinamika Keuangan dan Perbankan, Vol. 3 No. 1, pp: 126-142.

Haryuda, Agil Anggara, 2013, Pengaruh Tingkat Kesadaran, Pengetahuan Dan Pemahaman Peraturan Perpajakan, Kondisi Keuangan Serta Tarif Pajak Terhadap Kepatuhan Membayar Pajak Wajib Pajak Badan. Naskah Publikasi. Universitas Muhammadiyah Surakarta.

Jotopurnomo, Cindy dan Yenni Mangoting. 2013.

Pengaruh Kesadaran Wajib Pajak, Kualitas Pelayanan Fiskus, Sanksi Perpajakan, Lingkungan Wajib Pajak Berada terhadap Kepatuhan Wajib Pajak Orang Pribadi di Surabaya. Tax and Accounting Review Vol 1, No 1, pp: 49-54.

Khasanah, Septiyani Nur. 2014. Pengaruh Pengetahuan Perpajakan, Modernisasi Sistem Administrasi Perpajakan, dan Kesadaran Wajib Pajak Terhadap Kepatuhan Wajib

Mardiasmo. 2016. Perpajakan-Edisi Terbaru. Yogyakarta: Andi Offset.

Mardiasmo. Perpajakan Edisi Revisi 2011. Yogyakarta : Andi Offset. 2011.

Megawangi, Cokorda Agung Meggy dan Putu Ery Setiawan.2017. Sosialisasi Perpajakan Memoderasi Pengaruh Kesadaran Wajib Pajak Dan Kualitas Pelayanan Pada Kepatuhan Wajib Pajak Badan. E-Jurnal
Akuntansi Universitas Udayana Vol.19.3. Juni 2017, pp: 2348-2377.

Mir'atusholihah, Srikandi Kumadji, dan Bambang Ismono. 2014. Pengaruh Pengetahuan Perpajakan, Kualitas Pelayanan Fiskus Dan Tarif Pajak Terhadap Kepatuhan Wajib Pajak (Studi Pada Wajib Pajak UMKM Di Kantor Pelayanan Pajak Pratama Di Malang Utara). Jurnal Fakultas Ilmu Administrasi Univeristas Brawijaya.

Mohammad Zain. 2008. Manajeman Perpajakan. Edisi Ketiga. Jakarta: Salemba Empat.

Muliari, Ni Ketut dan Putu Ery Setiawan. 2011. Pengaruh Persepsi Tentang Sanksi Perpajakan dan Kesadaran Wajib Pajak Pada Kepatuhan Pelaporan Wajib Pajak Orang Pribadi Di Kantor Pelayanan Pajak Pratama Depansar Timur.Jurnal Akuntansi dan Bisnis, Volume 2, pp: 1-23.

Nugroho, Aditya, Rita Andini, Kharis Raharjo, 2016. Pengaruh Kesadaran Wajib Pajak dan Pengetahuan Perpajakan Wajib Pajak Terhadap Kepatuhan Wajib Pajak Dalam Menbayar Pajak Penghasilan di KPP Semarang Journal Of Accounting, Volume 2 No.2 Maret 2016,pp: 1-13.

Nurmantu, Safri. 2010. Pengantar Perpajakan. Jakarta: Kelompok Yayasan Obor.

Nurlaela, Lina. 2018. Pengaruh Kesadaran Wajib Pajak Dan Kualitas Pelayanan Pajak Terhadap Kepatuhan Wajib Pajak Kendaraan Bermotor Pada Kantor Samsat 
Kabupaten Garut. Jurnal Wacana Ekonomi.

Vol. 17; No. 02, pp: 046-055.

Paramartha, I Putu Indra Pradnya, dan Ni Ketut

Rasmini. 2016. "Pengaruh Kualitas

Pelayanan, Pengetahuan Dan Sanksi

Perpajakan Pada Kepatuhan Wajib Pajak

Badan." E-Jurnal Akuntansi Universitas

Udayana Vol 15, pp: 641-666

Priantara, Diaz. 2012. Perpajakan Indonesia Edisi

2. Jakarta : Mitra Wacana Media.

Rahayu, Siti Kurnia dan Ely Suhayati. 2009.

Perpajakan Teori dan Teknis Perhitungan.

Yogyakarta : Graha Ilmu.

Ramadiansyah, Dimas, Nengah Sudjana dan

Dwiatmanto. 2014. Analisis Faktor-faktor

Yang Mempengaruhi Wajib Pajak Orang

Pribadi dalam Memenuhi Kewajiban

Membayar Pajak: Studi Kasus pada KPP

Pratama Singosari. Jurnal e-Perpajakan,

Vol. 1 No. 1, pp: 1-7.

Resmi, Siti, 2009. Perpajakan Teori dan Kasus.

Jakarta: Salemba Empat.

Ritonga, Pandapotan 2011, Analisis Pengaruh

Kesadaran dan Kepatuhan Wajib Pajak

Terhadap Kinerja Kantor Pelayanan Pajak

(KPP) dengan Pelayanan Wajib Pajak

Sebagai Variabel Intervening di KPP

MedanTimur, Universitas Islam Sumatera

Utara, Medan.

Rohmawati, Lusia. Prasetyono dan Yuni

Rimawati. 2012. Pengaruh Sosialisasi dan

Pengetahuan Perpajakan Terhadap Tingkat

Kesadaran dan Kepatuhan Wajib Pajak
(Studi pada Wajib Pajak Orang Pribadi yang Melakukan Kegiatan Usaha dan Pekerjaan Bebas pada KPP Pratama Gresik Utara). Proiding Simposium Nasional Perpajakan 4.

Rumengan, Jemmy dan Idham. 2015. Metode Penelitian Kualitatif dan Kuantitatif. Bandung : Citapustaka Media.

Sari, R.A.Vivi Yulian dan Neri Susanti. 2013. Faktor-Faktor yang Mempengaruhi Kepatuhan Wajib Pajak Dalam Membayar Pajak Kendaraan Bermotor (PKB) di Unit Pelayanan Pendapatan Provinsi (UPPP) Kabupaten Seluma. Jurnal Ekombis Review. Vol. 2 No.1, pp: 63-78.

Santoso, Wahyu. 2008. Analisis Resiko Ketidakpatuhan Wajib Pajak Sebagai Dasar Peningkatan Kepatuhan Wajib Pajak. Jurnal Keuangan Publik, Vol. 5 No. 1, pp: 85-137.

Siregar, Yuli Anita, Saryadi Saryadi dan Sari Listyorini. 2012. Pengaruh Pelayanan Fiskus dan Pengetahuan Perpajakan Terhadap Kepatuhan Wajib Pajak (Studi Empiris Terhadap Wajib Pjak di Semarang Tengah).Vol.1 No.1,pp: 1-9.

Supriyati dan Hidayati Nur, 2008. Pengaruh Pengetahuan Pajak dan Persepsi Wajib Pajak Terhadap Kepatuhan Wajib Pajak. Jurnal Akuntansi dan Teknologi Informasi, vol. 7 No. 1, Mei 2008, hal 41-50.

Soemarso. 2010. Asas dan Dasar Perpajakan. Bandung : Refika Aditama. 
Sugiyono. 2012. Metode Penelitian Kuantitatif Kualitatif dan R\&D. Bandung : Alfabeta.

Supadmi, Ni Luh. 2009. Meningkatkan Kepatuhan Wajib Pajak Melalui Kualitas Pelayanan. Audi Jurnal Akuntansi dan Bisnis, Vol. 4 No.2, pp: 1-14. Denpasar: Fakultas Ekonomi Universitas Udayana.

Supriyati dan Nurhidayati. 2008. Pengaruh Pengetahuan Pajak dan Persepsi Wajib Pajak Terhadap kepatuhan Wajib Pajak. Jurnal Akuntansi dan Teknologi Informasi, Vol. 7 No. 1, pp: 41-50.

Tahar, Afrizal dan Arnain Kartika Rachman, 2014, "Pengaruh Faktor Internal dan Faktor Eksternal Terhadap Kepatuhan Wajib Pajak", Jurnal Akuntansi dan Investasi, Vol 15, No 1, pp: 56-67.

Tambun, Sihar. 2016. Anteseden Kepatuhan Wajib Pajak Orang Pribadi dan Moderasi Sosialisasi Perpajakan. Jurnal Media Akuntansi Perpajakan, Vol.1, No.1, pp: 2640.

Tjiptono, Fandy. (2007). Strategi Pemasaran. Edisi Pertama. Yogyakarta: Andi Offset.

Waluyo. 2011.Perpajakan Indonesia. Edisi 10

Buku 1. Salemba Empat. Jakarta.

Widi, Widodo. 2010. Moralitas, Budaya dan Kepatuhan Pajak. Bandung: Alfabeta Widyaningsih, Aristanti. 2011. Hukum Pajak dan Perpajakan dengan Pendekatan Mind Map. Bandung: Alfabeta.

Winerungan Oktaviane Lidya. 2013. Sosialisasi Perpajakan, Pelayanan Fiskus dan Sanksi Perpajakan Terhadap Kepatuhan WPOP di
KPP Manado dan KPP Bitung. Fakultas Ekonomi Dan Bisnis Universitas Sam Ratulangi, Manado.Jurnal EMBA Vol. 1 No. 3, pp: 960-970.

Witono, Banu. 2008. Peran Pengetahuan Pajak Pada Kepatuhan Wajib Pajak. Jurnal Akuntansi dan Keuangan, Vol 7. No. 2, pp: 196-208.

Wuri Manik Asri, Ni Ketut. 2009. Pengaruh Kualitas Pelayanan, Biaya Kepatuhan Pajak, dan Kesadaran Wajib Pajak pada Kepatuhan Pelaporan Wajib Pajak Badan yang Terdaftar di Kantor Pelayanan Pajak Madya Denpasar. Universitas Udayana.

Yogatama, Arya. 2014. Analisis Faktor-Faktor yang Mempengaruhi Kepatuhan Wajib Pajak Orang Pribadi (Studi di Wilayah KPP Pratama Semarang Candisari). Fakultas Ekonomika dan Bisnis Universitas Diponegoro. Semarang. 